\title{
Chronic and Acute Effects of Different Antihypertensive Drugs on Femoral Artery Relaxation of L-NAME Hypertensive Rats
}

\author{
M. SLÁDKOVÁ ${ }^{1}$, S. KOJŠOVÁ ${ }^{1}$, L. JENDEKOVÁ ${ }^{1}$, O. PECHÁŇOVÁ ${ }^{1,2}$ \\ ${ }^{1}$ Institute of Normal and Pathological Physiology and Centre of Excellence for Cardiovascular \\ Research, Slovak Academy of Sciences, Bratislava, Slovak Republic and ${ }^{2}$ Institute of Physiology, \\ Academy of Sciences of the Czech Republic, Prague, Czech Republic \\ Received July 4, 2007 \\ Accepted August 28, 2007 \\ On-line available September 5, 2007
}

\begin{abstract}
Summary
We aimed to compare the effects of chronic and acute administration of structurally different antihypertensives, diuretics - indapamide and hydrochlorothiazide, ACE inhibitor - captopril and indapamide+captopril combination on endothelium-dependent relaxation of femoral artery isolated from nitric oxide (NO)-deficient rats. In the chronic experiment, femoral artery was isolated from Wistar rats receiving L-NAME $(40 \mathrm{mg} / \mathrm{kg} /$ day $)$ solely or with indapamide (1 mg/kg/day), hydrochlorothiazide (10 mg/kg/day), captopril (10 mg/kg/day), and indapamide+captopril combination for seven weeks. In the acute in vitro experiment, the incubation medium with femoral artery isolated from L-NAMEhypertensive rats was supplemented with investigated antihypertensives in the same concentration $10^{-4} \mathrm{~mol} / 1$. Interestingly, chronic L-NAME treatment did not cause a reduction of vasorelaxation. Indapamide+captopril elevated relaxation above the control level and completely prevented blood pressure increase induced by L-NAME. Acute incubation with captopril only or indapamide+captopril improved relaxation of femoral artery isolated from L-NAMEhypertensive rats, while the incubation with all antihypertensives increased vasorelaxation of femoral artery isolated from control Wistar rats. In conclusion, NO might be involved in the indapamide- and hydrochlorothiazide-induced improvement of vasorelaxation, while different vasorelaxing factors (prostacyclin, EDHF) contribute to the captoprilinduced improvement of vasorelaxation. During the chronic treatment additive and synergic effects of indapamide and captopril may contribute to the prevention of hypertension and increase of vasorelaxation.
\end{abstract}

\section{Key words}

L-NAME-induced hypertension $\bullet$ Indapamide $\bullet$ Hydrochlorothiazide $\bullet$ Captopril $\bullet$ Femoral artery $\bullet$ Vasorelaxation

\section{Introduction}

Hypertension remains one of the leading causes of morbidity and mortality in most of the developed countries. Many hypertensive patients suffer from concomitant diseases or complications associated with high blood pressure (Šimko 2002, 2007). It is quite difficult to pick up the initial and additional antihypertensive agents that are simultaneously beneficial in the management of these comorbidities. Much data on the 
safety and therapeutic value of diuretics, beta blockers, calcium-channel blockers, angiotensin-converting enzyme inhibitors, and angiotensin receptor blockers in reducing blood pressure and preventing clinical disease have been accumulated now (Cohn 2001).

While studying effects of different antihypertensives, it seems to be especially important to analyze their interference with the L-arginine-nitric oxide pathway, renin-angiotensin-aldosterone system, sympathetic nervous system and oxidative status. Protection of physiological functions of these systems may reduce cardiovascular remodeling and renal damage (Šimko et al. 2003, Zicha et al. 2006a, Pecháňová et al. 2006, Kojšová et al. 2006, Kristek et al. 2007).

ACE inhibitors and diuretics belong to the important tools in blood pressure reduction. ACE inhibitor, captopril, which inhibits angiotensin II formation, causes blood pressure decrease, vasorelaxation (Johns et al. 1984, Török et al. 2002), cardioprotection (Šimko and Šimko 1999, Konstam et al. 2000, Bernátová et al. 2000) and renoprotection (Manley 2000, Pecháňová et al. 2006). In contrast to hydrochlorothiazide, a thiazide-like diuretic indapamide has been suggested to possess vasorelaxing and antioxidant properties besides its diuretic effect (Uehara et al. 1990, Kojšová et al. 2006). Experimental studies point to the fact that reduction of blood pressure and prevention of left ventricular hypertrophy development, induced by indapamide treatment, is associated with the increase of NO synthase activity (Hayakawa et al. 1997).

The aim of our study was to evaluate the acetylcholine-induced relaxation of femoral artery using NO-deficient model of hypertension developed by chronic administration of $\mathrm{N}^{\mathrm{G}}$-nitro-L-arginine methyl ester (L-NAME). The effects of treatment with indapamide, hydrochlorothiazide, captopril or combination of indapamide and captopril on the prevention of L-NAME-induced hypertension and femoral artery relaxation were studied. Furthermore, the acute in vitro effects of the investigated antihypertensives on the femoral artery relaxation were analyzed.

\section{Material and Methods}

\section{Animals and treatment}

All procedures and experimental protocols were approved by the Ethical Committee of the Institute of Normal and Pathological Physiology SAS, and conform to the European Convention on Animal Protection and
Guidelines on Research Animal Use. The animals were housed in an air-conditioned room at a stable temperature $\left(22-24{ }^{\circ} \mathrm{C}\right)$ and humidity (45-60 \%) on a 12:12 h light/dark cycle and maintained on a standard pellet diet and tap water ad libitum. Daily water consumption was estimated one week before the experiment and controlled during the treatment.

In the chronic treatment, adult 12-week-old Wistar rats were divided into six groups: control $(n=6)$, group treated with $\mathrm{N}^{\mathrm{G}}$-nitro-L-arginine methyl ester (L-NAME, $40 \mathrm{mg} / \mathrm{kg} / \mathrm{day}, \mathrm{n}=6$ ); other groups received L-NAME plus indapamide $(1 \mathrm{mg} / \mathrm{kg} / \mathrm{day}, \mathrm{n}=6)$ or hydrochlorothiazide $(10 \mathrm{mg} / \mathrm{kg} / \mathrm{day}, \mathrm{n}=6)$ or captopril $(10 \mathrm{mg} / \mathrm{kg} /$ day, $\mathrm{n}=6)$ or combination of indapamide and captopril $(\mathrm{n}=6)$. The antihypertensives investigated were dissolved in the drinking water and administered orally for 7 weeks. At the end of the treatment the body weight (BW) and left ventricular weight (LVW) were measured and LVW to $\mathrm{BW}$ ratio was calculated (LVW/BW).

In the acute experiment, the bath medium was supplemented with the antihypertensives (individually except the indapamide+captopril combination) in the same concentration $10^{-4} \mathrm{~mol} / 1$ and the analysis of vasorelaxation was performed on femoral artery of normotensive Wistar rats and L-NAME hypertensive rats.

\section{Blood pressure measurement}

The blood pressure (BP) was measured noninvasively by the tail-cuff plethysmography using the Statham Pressure Transducer P23XL (Hugo Sachs, Germany) each weak. The average value was calculated from five successive BP measurements.

\section{In vitro assessment of acetylcholine-induced relaxation} by wire myograph

The endothelium-dependent relaxations were tested on femoral artery rings (approximately $1 \mathrm{~mm}$ long) using the Mulvany-Helper small vessel myograph (Dual Wire Myograph System 410A, DMT A/S, Aarhus, Denmark) under the isometric conditions. During the whole experiment the bath medium - Krebs-Ringer solution (containing in $\mathrm{mmol} / \mathrm{l}: \mathrm{NaCl} 118, \mathrm{KCl} 5$, $\mathrm{NaHCO}_{3} 25, \mathrm{MgSO}_{4} \cdot \mathrm{H}_{2} \mathrm{O}$ 1.2, $\mathrm{KH}_{2} \mathrm{PO}_{4} 1.2, \mathrm{CaCl}_{2} 2.5$, EDTA 0.03, ascorbic acid 1.1, glucose 11), pH 7.4 was oxygenated (mixture of $95 \% \mathrm{O}_{2}$ and $5 \% \mathrm{CO}_{2}$ ) and kept at $37{ }^{\circ} \mathrm{C}$. All the chemicals used were purchased from Sigma Chemicals Co. (Germany). In the chronic experiment the vessels were preconstricted with serotonin $\left(10^{-5} \mathrm{~mol} / \mathrm{l}\right)$. When the contraction reached a steady-state 


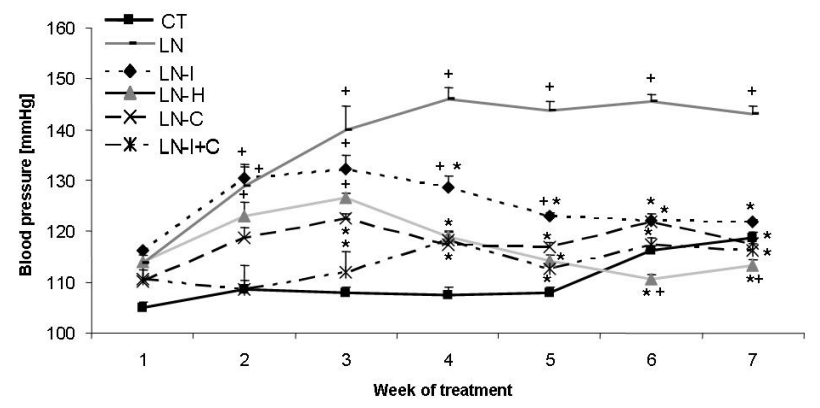

Fig. 1. The effect of L-NAME and L-NAME with indapamide, hydrochlorothiazide, captopril or indapamide+captopril combination on the development of blood pressure. Wistar control rats (CT); rats treated with L-NAME $40 \mathrm{mg} / \mathrm{kg} / \mathrm{day}(\mathrm{LN})$, rats treated with L-NAME plus indapamide $1 \mathrm{mg} / \mathrm{kg} /$ day (LN-I), hydrochlorothiazide $10 \mathrm{mg} / \mathrm{kg} /$ day $(\mathrm{LN}-\mathrm{H})$, captopril $10 \mathrm{mg} / \mathrm{kg} /$ day $(\mathrm{LN}-\mathrm{C})$, indapamide+captopril combination $1 \mathrm{mg} / \mathrm{kg} / \mathrm{day}+$ $10 \mathrm{mg} / \mathrm{kg} /$ day $(\mathrm{LN}-\mathrm{I}+\mathrm{C})$. Results are shown as mean \pm S.E.M. ${ }^{+} p<0.05$ vs. CT, $* p<0.05$ vs. LN.

the acetylcholine was added in a cumulative manner $\left(10^{-8}, 10^{-7}, 10^{-6}, 10^{-5} \mathrm{~mol} / \mathrm{l}\right)$. In the acute experiments the vessels were incubated with the substances investigated $\left(10^{-4} \mathrm{~mol} / \mathrm{l}\right)$ for $30 \mathrm{~min}$ before the preconstriction. The relaxations were expressed as a percentage of serotonininduced contraction. Average value of vasorelaxation was calculated as a mean value of vasorelaxation reached in the groups based on the individual dose-response curves.

\section{Statistical analysis}

The results are expressed as means \pm SEM. Significance of the differences between groups was determined by multifactorial analysis of variance (ANOVA) followed by Bonferroni post-hoc test. Probability values less than 0.05 were considered to be significant.

\section{Results}

\section{Blood pressure}

Blood pressure of control rats as well as of rats receiving L-NAME and L-NAME simultaneously with indapamide, hydrochlorothiazide, captopril, and indapamide+captopril combination is shown in Figure 1. Captopril and indapamide+captopril significantly decreased blood pressure rise from the 2nd week of treatment in comparison with the group receiving LNAME only. Both diuretics - indapamide and hydrochlorothiazide - were able to decrease blood pressure rise from the 3 rd week of treatment (Fig. 1).

\section{Body weight, left ventricular weight and $L V W / B W$ ratio}

The body weight was not influenced by
Table 1. The effect of L-NAME and L-NAME with indapamide, hydrochlorothiazide, captopril or indapamide + captopril combination on the body weight (BW), left ventricular weight (LVW) and left ventricular weight/body weight ratio (LVW/BW).

\begin{tabular}{lcccc}
\hline & & $\begin{array}{c}\text { BW } \\
(\mathbf{g})\end{array}$ & $\begin{array}{c}\text { LVW } \\
\mathbf{( m g )}\end{array}$ & $\begin{array}{c}\text { LVW/BW } \\
\mathbf{( m g / g )}\end{array}$ \\
\hline$C T$ & 6 & $341 \pm 7$ & $465 \pm 29$ & $1.36 \pm 0.07$ \\
$L N$ & 6 & $349 \pm 10$ & $536 \pm 20^{+}$ & $1.54 \pm 0.06^{+}$ \\
$L N-I$ & 6 & $357 \pm 11$ & $482 \pm 14^{*}$ & $1.36 \pm 0.06^{*}$ \\
$L N-H$ & 6 & $334 \pm 15$ & $441 \pm 17^{*}$ & $1.35 \pm 0.08^{*}$ \\
$L N-C$ & 6 & $339 \pm 6$ & $408 \pm 4^{*}$ & $1.21 \pm 0.03 *$ \\
$L N-I+C$ & 6 & $305 \pm 16^{*}$ & $405 \pm 5 *$ & $1.29 \pm 0.05 *$ \\
\hline
\end{tabular}

Wistar control rats (CT); rats treated with L-NAME $40 \mathrm{mg} / \mathrm{kg} /$ day $(\mathrm{LN})$, rats treated with L-NAME plus indapamide $1 \mathrm{mg} / \mathrm{kg} /$ day (LN-I), hydrochlorothiazide $10 \mathrm{mg} / \mathrm{kg} /$ day $(\mathrm{LN}-\mathrm{H})$, captopril $10 \mathrm{mg} / \mathrm{kg} /$ day (LN-C), indapamide+captopril combination $1 \mathrm{mg} / \mathrm{kg} /$ day $+10 \mathrm{mg} / \mathrm{kg} /$ day $(\mathrm{LN}-\mathrm{I}+\mathrm{C})$. Results are shown as average \pm S.E.M. ${ }^{+} p<0.05$ vs. CT. $* p<0.05$ vs. LN.

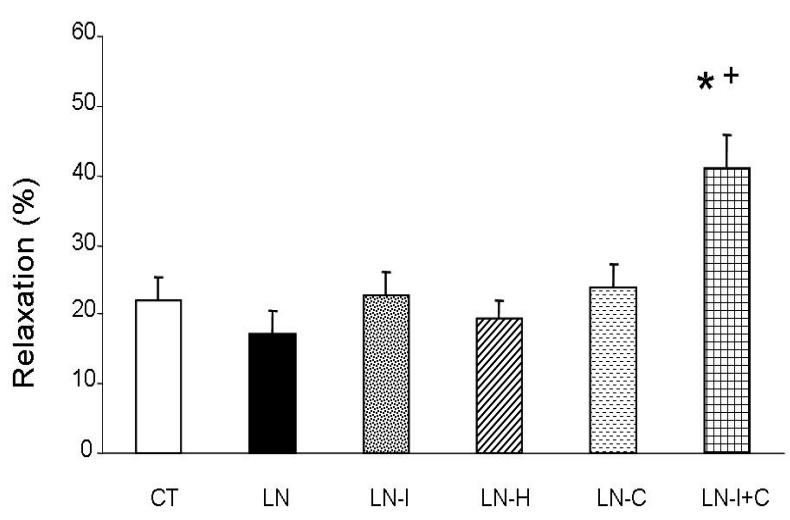

Fig. 2. Averaged acetylcholine-induced relaxations of femoral artery isolated from rats treated with L-NAME or L-NAME with indapamide, hydrochlorothiazide, captopril or indapamide+ captopril combination. Wistar control rats (CT); rats treated with L-NAME $40 \mathrm{mg} / \mathrm{kg} /$ day $(\mathrm{LN})$, rats treated with L-NAME plus indapamide $1 \mathrm{mg} / \mathrm{kg} /$ day $\quad(\mathrm{LN}-\mathrm{I})$, hydrochlorothiazide $10 \mathrm{mg} / \mathrm{kg} /$ day (LN-H), captopril $10 \mathrm{mg} / \mathrm{kg} /$ day (LN-C), and indapamide+captopril combination $1 \mathrm{mg} / \mathrm{kg} / \mathrm{day}+10 \mathrm{mg} / \mathrm{kg} / \mathrm{day}$ $(\mathrm{LN}-\mathrm{I}+\mathrm{C})$. Results are shown as mean \pm S.E.M. ${ }^{+} \mathrm{p}<0.05$ vs. CT, $* \mathrm{p}<0.05$ vs. LN.

L-NAME alone or plus indapamide, hydrochlorothiazide, and captopril treatment. The indapamide+captopril combination decreased BW significantly. Left ventricular weight was increased significantly in rats receiving L-NAME. The antihypertensive treatment decreased left ventricular weight in comparison to the L-NAME group. $\mathrm{LVW} / \mathrm{BW}$ was increased in L-NAME hypertensive rats in comparison with the control Wistar rats. This augmentation was prevented by concomitant treatment with all antihypertensives (Table 1). 


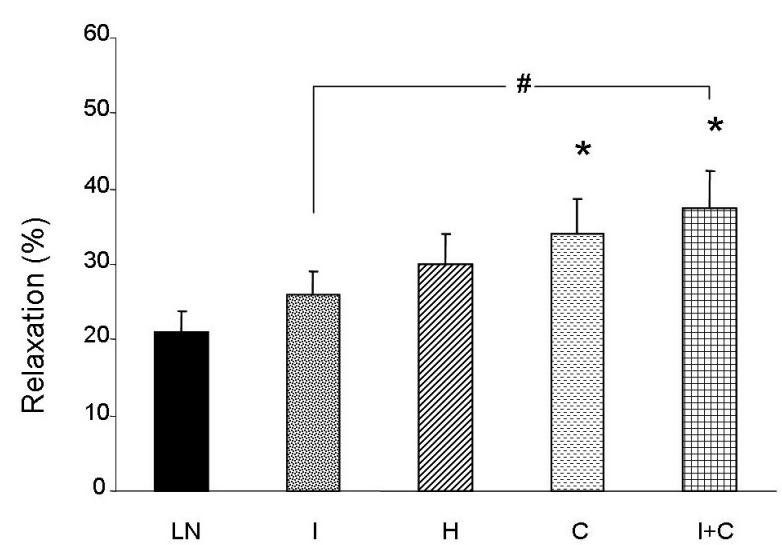

Fig. 3. Averaged acetylcholine-induced relaxations of femoral artery isolated from L-NAME-hypertensive rats and incubated with indapamide, hydrochlorothiazide, captopril or indapamide+captopril. Non-incubated vessels from L-NAMEhypertensive rats (LN); vessels incubated in the same concentration $10^{-4} \mathrm{~mol} / \mathrm{l}$ with indapamide (I), hydrochlorothiazide $(\mathrm{H})$, captopril (C), indapamide+captopril combination (I+C). Results are shown as mean \pm S.E.M. $* p<0.05$ vs. $\mathrm{LN}^{*}{ }^{*} \mathrm{p}<0.05$ I vs. I+C.

In vitro assessment of acetylcholine-induced relaxation by wire myograph

\section{Chronic experiments}

Chronic L-NAME treatment did not decrease the acetylcholine-induced relaxations of femoral artery. We have recorded a significant increase of averaged acetylcholine-induced relaxations only after chronic indapamide+captopril combination treatment. This increase was significant compared to both control and L-NAME treated groups (Fig. 2).

\section{Acute experiments}

Incubation of femoral artery isolated from L-NAME-hypertensive rats with captopril and indapamide+captopril improved significantly the averaged acetylcholine-induced relaxation compared to non-incubated vessels from L-NAME-hypertensive rats. Indapamide+captopril incubation also caused significant improvement of relaxations in comparison to femoral artery incubated with indapamide alone (Fig. 3). Incubation of femoral artery isolated from Wistar control rats with indapamide, hydrochlorothiazide, captopril, and indapamide+captopril led to the significant augmentation of averaged acetylcholine-induced relaxations in comparison to non-incubated vessels (Fig. 4).

\section{Discussion}

This study demonstrated that antihypertensive

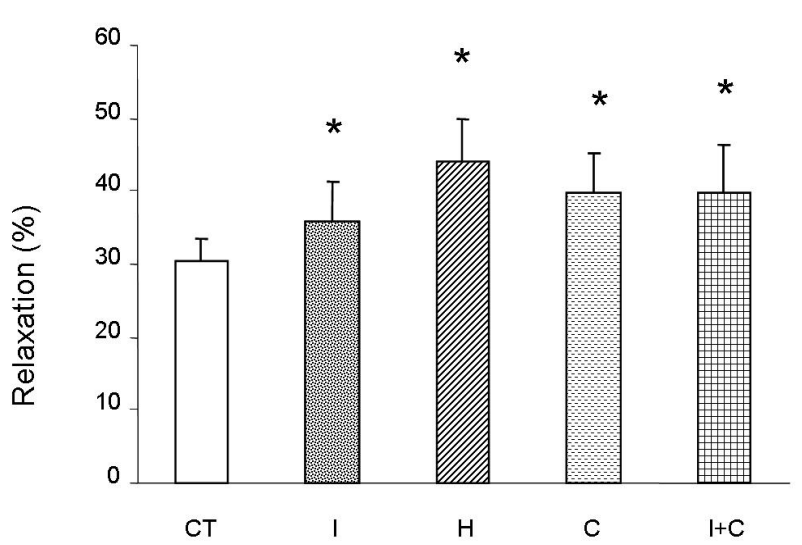

Fig. 4. Averaged acetylcholine-induced relaxations of femoral artery isolated from control Wistar rats and incubated with indapamide, hydrochlorothiazide, captopril and indapamide+ captopril combination. Non-incubated vessels (CT); vessels incubated in the same concentration $10^{-4} \mathrm{~mol} / \mathrm{I}$ with indapamide (I), hydrochlorothiazide $(\mathrm{H})$, captopril $(\mathrm{C})$, indapamide+captopril combination $(\mathrm{I}+\mathrm{C})$. Results are shown as mean \pm S.E.M. $* \mathrm{p}<0.05$ vs. CT.

treatments (indapamide, hydrochlorothiazide, captopril, or indapamide+captopril combination) prevented blood pressure increase and left ventricular hypertrophy development induced by L-NAME. At the end of experiment, there was no significant difference between the blood pressure of rats receiving L-NAME simultaneously with antihypertensives and normotensive Wistar rats.

Interestingly, in our experiment, chronic L-NAME treatment did not decrease the acetylcholineinduced relaxation of femoral artery. Indapamide+ captopril combination along with L-NAME was able to increase relaxation responses of femoral artery above the control level. In vitro incubation of femoral artery isolated from L-NAME-hypertensive rats with captopril and indapamide+captopril improved significantly acetylcholine-induced relaxations compared to nonincubated vessels from L-NAME-hypertensive rats. Finally, all antihypertensive drugs were able to increase relaxation responses of femoral artery isolated from normotensive Wistar rats.

The new group of thiazide-like diuretics, including indapamide, possess minimal diuretic but significant antihypertensive effects. The probable mechanism of their action include the restoration of electrolyte balance, diminished responses to vasoconstrictor agents and reduced peripheral resistance (Levy et al. 1990, Szilvassy et al. 2001). In agreement with our study, indapamide significantly reduced blood pressure in DOCA-salt sensitive rats due to a decrease of peripheral resistance (Levy et al. 1990). On the basis of 
in vitro experiments Boulanger et al. (1993) reported that indapamide inhibited endothelium-dependent vasoconstriction of aorta from spontaneously hypertensive rats. In our acute experiments, indapamide was not able to increase relaxation of femoral artery isolated from LNAME hypertensive rats. On the other hand, it increased relaxation of femoral artery isolated from control Wistar rats. In human brachial arteries Pickkers et al. (1998) documented the direct vasodilator effect of hydrochlorothiazide which was associated with activation of potassium channels. In our experimental conditions, hydrochlorothiazide, similarly like indapamide, had no effect on the relaxation responses of femoral artery isolated from L-NAME hypertensive rats both after chronic treatment or after acute incubation. However, after acute incubation both diuretics increased relaxation responses of femoral artery isolated from control Wistar rats. Thus, we hypothesized that nitric oxide may be involved in the improvement of vasorelaxation induced by indapamide and hydrochlorothiazide.

Beside direct reduction of angiotensin II and elevation of bradykinin production, the increase of NO generation and decrease of reactive oxygen species (ROS) formation is probably responsible for beneficial effects of ACE inhibitors (Wiemer et al. 1997, Pecháňová et al. 1997, 2006, 2007, Šimko and Šimko 1999, Šimko et al. 2001, Gvozdjáková et al. 1999). The presence of the thiol group in the captopril molecule contributes to its strong antioxidative potential (Török et al. 2002, Zicha et al. 2006b, Pecháňová et al. 2006, 2007). Bernátová et al. (1996) demonstrated that captopril (100 mg/kg/day) prevented L-NAME-induced hypertension and left ventricular hypertrophy without affecting NO synthase activity. In accordance with this finding, in the present experiment chronic captopril administration in ten time lower dose $(10 \mathrm{mg} / \mathrm{kg} /$ day) prevented blood pressure rise due to L-NAME treatment, however, without affecting endothelium-dependent relaxation of femoral artery. On the other hand, Dahlof and Hansson (1993) showed that enalapril reduced blood pressure via dilatation and decreased peripheral resistance in men with previously non-treated essential hypertension. Keaton et al. (1998) also demonstrated that chronic captopril treatment improved vasorelaxation of spontaneously hypertensive rats. Our findings confirmed the beneficial effect of captopril only in acute experiments in which this ACE inhibitor increased the relaxation responses of femoral artery isolated from both L-NAME hypertensive and control Wistar rats. Thus, we hypothesized that besides NO, other substances such as prostacyclin and endothelium-derived hyperpolarizing factor (EDHF) may be involved in the improvement of vasorelaxation after both acute captopril and chronic indapamide+captopril combination treatment. Interestingly, chronic captopril treatment did not improve vasorelaxation also in spontaneously hypertensive rats where the production of NO was not blocked (Sládková et al. 2005). We assume that the dose of captopril ( $10 \mathrm{mg} / \mathrm{kg} /$ day $)$ used in the chronic experiment was not able to enhanced sufficiently the production of NO with subsequent vasorelaxation.

We showed that indapamide+captopril combination prevented most effectively the blood pressure elevation. Several studies pointed out the fact that the antihypertensive therapy combining drugs from different classes provide an additive effect and thus minimize the possibility of adverse effects depending on the dose used (Toblli et al. 2003). Low-dose combination treatment with perindopril or captopril and indapamide had been shown to increase NO synthase activity and endothelium-dependent relaxation in spontaneously hypertensive and Dahl salt-sensitive rats (Hayakawa et al. 1997, Sládková et al. 2005, Kojšová et al. 2005, 2006). In this experiment, however, indapamide was not able to exceed the inhibitory effect of L-NAME and to enhance vasorelaxation.

In conclusion, our study demonstrated that indapamide+captopril combination along with L-NAME was able to increase relaxation responses of femoral artery above the control level. Acute incubation with captopril or indapamide+captopril improved relaxation responses of femoral artery from L-NAME hypertensive rats. Thus, nitric oxide is probably involved in indapamide-induced improvement of vasorelaxation, while other vasorelaxing factors such as prostacyclin or EDHF participate in the captopril-induced improvement of vasorelaxation. During the chronic treatment the additive and synergic effects of indapamide and captopril may contribute to the increase of vasorelaxation.

\section{Acknowledgements}

The study was supported by the research grant VEGA 2/6148/26, 1/3429/06 and APVV-0586-06. Technical assistance of Y. Hanáčková is highly appreciated. Preliminary results were presented at "Nitric Oxide" symposium in Tučepi, September 21-24, 2005 (Sládková et al. 2006, Kojšová et al. 2006). 


\section{References}

BERNÁTOVÁ I, PECHÁŇOVÁ O, ŠIMKO F: Captopril prevents NO-deficient hypertension and left ventricular hypertrophy without affecting nitric oxide synthase activity in rats. Physiol Res 45: 311-316, 1996.

BERNÁTOVÁ I, PECHÁŇOVÁ O, PELOUCH V, ŠIMKO F: Regression of chronic L-NAME-treatment-induced left ventricular hypertrophy: effect of captopril. J Mol Cell Cardiol 32: 177-185, 2000.

BOULANGER CM, MOMBOULI JV, VANHOUTTE PM: Indapamide inhibits endothelium-dependent contractions in the aorta of the spontaneously hypertensive rat. Fundam Clin Pharmacol 7: 443-448, 1993.

COHN JN: Arterial compliance to stratify cardiovascular risk: more precision in therapeutic decision making. $A m J$ Hypertens 14 (8 Part 2): 258S-263S, 2001.

DAHLOF B, HANSSON L: The influence of antihypertensive therapy on the structural arteriolar changes in essential hypertension: different effects of enalapril and hydrochlorothiazide. J Intern Med 234: 271-279, 1993.

GVOZDJÁKOVÁ A, ŠIMKO F, KUCHARSKÁ J, BRAUNOVÁ Z, PŠENEK P, KYSELOVIČ J: Captopril increased mitochondrial coenzyme $\mathrm{Q}_{10}$ level, improved respiratory chain function and energy production in the left ventricle in rabbits with smoke mitochondrial cardiomyopathy. Biofactors 10: 61-65, 1999.

HAYAKAWA H, COFFEE K, RAIJ L: Endothelial dysfunction and cardiorenal injury in experimental salt-sensitive hypertension: effects of antihypertensive therapy. Circulation 96: 2407-2413, 1997.

JOHNS DW, AYERS CR, WILLIAMS SC: Dilation of forearm blood vessels after angiotensin-converting-enzyme inhibition by captopril in hypertensive patients. Hypertension 6: 545-550, 1984.

KEATON AK, WHITE CR, BERECEK KH: Captopril treatment and its withdrawal prevents impairment of endothelium-dependent responses in the spontaneously hypertensive rat. Clin Exp Hypertens 20: 847-866, 1998.

KOJŠOVÁ S, JENDEKOVÁ L, CSIZMADIOVÁ Z, VRANKA I, JANÍKOVÁ R, PECHÁŇOVÁ O: The effect of indapamide and captopril on blood pressure, nitric oxide generation and oxidant status in spontaneously hypertensive rats. Physiol Res 54: 54P, 2005.

KOJŠOVÁ S, JENDEKOVÁ L, SLÁDKOVÁ M, CSIZMADIOVÁ Z, PAULIS L', PECHÁŇOVÁ O: Different effects of indapamide and hydrochlorothiazide treatment on spontaneous and L-NAME-induced hypertension. Physiol Res 55: 6P, 2006.

KOJŠOVÁ S, JENDEKOVÁ L, ZICHA J, KUNEŠ J, ANDRIANTSITOHAINA R, PECHÁŇOVÁ O: The effect of different antioxidants on nitric oxide production in hypertensive rats. Physiol Res 55 (Suppl 1): S3-S16, 2006.

KONSTAM MA, PATTEN RD, THOMAS I, RAMAHI T, LA BRESH K, GOLDMAN S, LEWIS W, GRADMAN A, SELF KS, BITTNER V, RAND W, KINAN D, SMITH JJ, FORD T, SEGAL R, UDELSON JE: Effects of losartan and captoprilon left ventricular volumes in elderly patients with heart failure: results of the ELITE ventricular function substudy. Am Heart $J$ 139: 1081-1087, 2000.

KRISTEK F, KOPRDOVÁ R, CEBOVÁ M: Long-term effects of early administered sildenafil and NO donor on the cardiovascular system of SHR. J Physiol Pharmacol 58: 33-43, 2007.

LEVY BI, POITEVIN P, SAFAR ME: Effects of indapamide on the mechanical properties of the arterial wall in deoxycorticosterone acetate-salt hypertensive rats. Am J Cardiol 65 (17): 28H-32H, 1990.

MANLEY HJ: Role of angiotensin-converting-enzyme inhibition in patients with renal disease. Am J Health Syst Pharm 57 (Suppl 1): S12-S18, 2000.

PECHÁŇOVÁ O: Contribution of captopril thiol group to the prevention of spontaneous hypertension Physiol Res 56 (Suppl 2): S41-S48, 2007.

PECHÁŇOVÁ O, BERNÁTOVÁ I, PELOUCH V, ŠIMKO F: Protein remodelling of the heart in NO-deficient hypertension: the effect of captopril. J Mol Cell Cardiol 29: 3365-3374, 1997.

PECHÁŇOVÁ O, MATUŠKOVÁ J, CAPÍKOVÁ D, JENDEKOVÁ L, PAULIS L, ŠIMKO F: Effect of spironolactone and captopril on nitric oxide and S-nitrosothiol formation in kidney of L-NAME-treated rats. Kidney Int 70: 170-176, 2006.

PICKKERS P, HUGHES AD, RUSSEL FGM, THIEN T, SMITS P: Thiazide-induced vasodilation in humans is mediated by potassium channel activaton. Hypertension 32: 1071-1076, 1998. 
ŠIMKO F: Physiologic and pathologic myocardial hypertrophy-physiologic and pathologic regression of hypertrophy? Med Hypotheses 58: 11-14, 2002.

ŠIMKO F: Is NO the king? Pathophysiological benefit with uncertain clinical impact. Physiol Res 56 (Suppl 2): S1-S6, 2007.

ŠIMKO F, ŠIMKO J: Heart failure and angiotensin converting enzyme inhibition: problems and perspectives. Physiol Res 48: 1-8, 1999.

ŠIMKO F, MARTINKA P, BRASSANOVÁ J, KLIMAŠ J, GVOZDJÁKOVÁ A, KUCHARSKÁ J, BADA V, HULÍN I, KYSELOVIČ J: Passive cigarette smoking induced changes in reactivity of the aorta in rabbits: efffect of captopril. Pharmazie 56: 431-432, 2001.

ŠIMKO F, ŠIMKO J, FABRYOVÁ M: ACE-inhibition and angiotensin II receptor blockers in chronic heart failure: pathophysiological consideration of the unresolved battle. Cardiovasc Drugs Ther 17: 287-90, 2003.

SLÁDKOVÁ M, KOJŠOVÁ S, PECHÁŇOVÁ O: Effect of chronic indapamide, hydrochlorothiazide and captopril treatment on relaxation of femoral artery in spontaneously hypertensive rats. Physiol Res 54: 57P, 2005.

SLÁDKOVÁ M, KOJŠOVÁ S, PECHÁŇOVÁ O: Comparison of femoral artery relaxation after acute and chronic administration of indapamide, hydrochlorothiazide and captopril in spontaneously hypertensive rats. Physiol Res 55: 10P, 2006.

SZILVASSY Z, CSONT T, PALIC T, DROY-LEFAIX M, FERDINANDY P: Nitric oxide, peroxynitrite and cGMP in atherosclerosis-induced hypertension in rabbits: beneficial effects of cicletanine. J Vasc Res 38: 39-46, 2001.

TOBLLI JE, DEROSA G, RIVAS C, CAO G, PIORNO P, PAGANO P, FORCADA P: Cardiovascular protective role of a low-dose antihypertensive combination in obese Zucker rats. J Hypertens 21: 611-620, 2003.

TÖRÖK J, BABÁL P, MATUŠKOVÁ J, LUPTÁK I, KLIMEŠ I, ŠIMKO F: Impaired endothelial function of thoracic aorta in hereditary hypertriglyceridemic rats. Ann N Y Acad Sci 967: 469-475, 2002.

UEHARA Y, SHIRAHASE H, NAGATA T, ISHIMITSU T, MORISHITA S, OSUMI S, MATSUOKA H, SUGIMOTO T: Radical scavengers of indapamide in prostacyclin synthesis in rat smooth muscle cell. Hypertension 15: 216-224, 1990.

WIEMER G, LINZ W, HATRIK S, SCHOLKENS BA, MALINSKI T: Angiotensin-converting enzyme inhibition alters nitric oxide and superoxide release in normotensive and hypertensive rats. Hypertension 30: 1183-1190, 1997.

ZICHA J, DOBEŠOVÁ Z, KUNEŠ J: Antihypertensive mechanisms of chronic captopril or N-acetylcysteine treatment in L-NAME hypertensive rats. Hypertens Res 29: 1021-1027, 2006 a.

ZICHA J, PECHÁŇOVÁ O, ČAČÁNYIOVÁ S, CEBOVÁ M, KRISTEK F, TÖRÖK J, ŠIMKO F, DOBEŠOVÁ Z, KUNEŠ J: Hereditary hypertriglyceridemic rat: a suitable model of cardiovascular disease and metabolic syndrome? Physiol Res 55 (Suppl 1): S49-63, 2006b.

\section{Corresponding author}

O. Pecháňová, Institute of Normal and Pathological Physiology, Slovak Academy of Sciences, Sienkiewiczova 1, 81371 Bratislava, Slovak Republic. Fax: +421-2-52968516. E-mail: olga.pechanova@savba.sk 